\title{
How reggies regulate regeneration and axon growth
}

\author{
Claudia A. O. Stuermer
}

\begin{abstract}
The microdomain-forming proteins reggie-1 and reggie-2 (alias flotillins) were found to be upregulated in axon-regenerating fish retinal ganglion cells (RGCs). They were subsequently shown to be indispensible for axon regeneration and neurite extension in fish and mammals. Our current concept proposes that reggies - often together with the cellular Prion protein $(\mathrm{PrP})$-regulate the turnover of membrane and specific membrane proteins at the growth cone, which is the prerequisite for neurite elongation and guidance.
\end{abstract}

Keywords Axon regeneration - Mammalian CNS · Reggie upregulation $\cdot$ Targeted delivery $\cdot$ Membrane proteins

\section{Introduction}

In the search for the mechanisms underlying success and failure of axon regeneration in the central nervous system (CNS), it has been recognized that extrinsic (environmental) as well as intrinsic factors decide whether or not neurons regrow axons (Liu et al. 2011). It has meanwhile become clear that neuron-intrinsic conditions that would allow powerful axon regrowth decline during the transition from embryonic to adult stages of neural development in mammals and that the sensitivity to inhibitors increases in postnatal neurons. Extrinsic factors are provided by glial cells at the site of lesion in form of inhibitors. Nogo-A made by oligodendrocytes is one of the strongest inhibitors of axon growth, which can collapse growth cones (Caroni and Schwab 1988; Chen et al. 2000). Many other non-permissive molecules are provided by the

C. A. O. Stuermer ( $\bowtie)$

Department of Biology, University of Konstanz,

78467 Konstanz, Germany

e mail: claudia.stuermer@uni konstanz.de glial scar and prevent axon elongation (Silver and Miller 2004). The importance of the extrinsic inhibitors and neuron-intrinsic properties (Benowitz and Yin 2007) was impressively illustrated by experiments from A. Aguayo's laboratory some 30 years ago: when the optic nerve of rats was replaced by a nerve graft from the growth permissive peripheral nervous system (PNS), retinal ganglion cell (RGC) axons, which would not spontaneously regenerate, grew over substantial distances and reached the brain (Richardson et al. 1980). Surprisingly, only $5 \%$ of the neurons extended long axons into the graft, whereas the majority $(95 \%)$ in the same retina would still not do so. It is not clear why $5 \%$ regrow but it must be connected to the differential ability of RGCs to upregulate specific growth-related proteins, which reflects their growth supportive intrinsic properties.

Curiously, CNS neurons in lower vertebrates (fish, amphibians) are highly successful in regenerating axons and repairing CNS fiber tracts after lesion (Gaze 1970), which correlates with the fact that all fish RGCs are able to upregulate the growthrelated proteins (found in the $5 \%$ rat RGCs) again emphasizing the significance of the neuron-intrinsic properties (Stuermer and Leppert 2000). Fish RGCs are perhaps the best example to demonstrate that neuron-intrinsic properties do not have to be so negative as in mammals. In contrast to neurons in rats, all fish RGCs upregulate mRNA and protein expression in response to axotomy and regenerate their axons. These neurons are able of coordinately generating cytoskeletal elements and of re-expressing cell adhesion molecules, receptors for growth factors and guidance cues and molecules for target recognition and synapse reformation-as if fish RGCs had a "master switch" turned on by axotomy to activate the gene expression program required to regrow an axon and restore appropriate connections.

The fish visual system is, therefore, a model system for the exploration of the cellular and molecular factors making up 
the cell-intrinsic properties underlying axon regeneration and, as discussed here, for identifying candidate factors for a forced upregulation in mammals to trigger regeneration.

The search for molecules being upregulated during axon growth in fish RGCs led to the discovery of two proteins, reggie-1 and reggie-2 (Schulte et al. 1997), which were later shown to be indispensible for axon growth and regenerationin fish as well as in mammals (Munderloh et al. 2009). Here, we will present a survey of the molecular and biochemical properties of reggie-1 and reggie-2, describe their role for axon growth and discuss the gradual elucidation of the mechanisms that reggies seem to activate and control.

\section{The identification of the reggie/flotillin proteins}

Reggie-1 and -2 were discovered as two 48 -kd proteins being upregulated in goldfish RGCs after optic nerve lesion (Schulte et al. 1997) and in some rat RGCs after PNS graft application (Lang et al. 1998). They were independently identified as lipid raft proteins, which become enriched in the floating fraction after sucrose density centrifugation of molecules insoluble in the nonionic detergent Triton-X100 and were named flotillins (Bickel et al. 1997). Immuno-electron microscopy-analyses from our work (Lang et al. 1998; Stuermer et al. 2001) showed that reggies/flotillins are not constituents of caveolae as had been suggested by Bickel and collegues (Bickel et al. 1997) but instead form their own type of microdomains - the reggie microdomains. Consistent with this notion is the fact that reggies are expressed at particularly high levels in neurons (Schulte et al. 1997; Bickel et al. 1997) and lymphocytes (Stuermer et al. 2004) representing cell types that do not possess caveolae (Fra et al. 1994). Reggies are associates of lipid rafts/microdomains at the cytoplasmic face of the plasma membrane and at membranes of specific types of vesicle that can be subsumed under trafficking vesicles; for instance, phagosomes in mammalian macrophages (Dermine et al. 2001) and Dictyostelium (Wienke et al. 2006), post-Golgi vesicles in Hela, Jurkat $\mathrm{T}$ cells and neurons (Morrow et al. 2002; Langhorst et al. 2008a) and glucose transporter 4 (Glut4) containing special cargo vesicles in adipocytes (Baumann et al. 2000). Thus, we suggest that reggies at specific types of vesicles participate in cargo transport (Stuermer 2010). Their widespread distribution implies that they subserve this function not only in neurons but in every single cell type examined to date. Incidentally, reggies are present in basically all species (except $C$. elegans), are evolutionarily highly conserved from fly to man and exist as reggielike proteins in plants and bacteria (Hinderhofer et al. 2009; Borner et al. 2005). They are members of the so-called SPFH (stomatin, prohibitin, flotillin and bacterial $\mathrm{HflK} / \mathrm{C}$ ) protein family, which also includes podocin (a protein of kidney podocytes) and erlin (Morrow and Parton 2005; Browman et al. 2007). These proteins share the so-called SPFH or head domain in their amino-terminal end containing hydrophobic stretches and residues for palmitoylation and myristoylation (Morrow et al. 2002; Neumann-Giesen et al. 2004) and mediate the association of reggie with the membrane. At their Cterminal end, reggies possess a predicted alpha helical coiledcoil tail domain promoting homo- and hetero oligomerization and thus formation of reggie clusters or reggie coats (Solis et al. 2007).

\section{Reggie/flotillin at trafficking vesicles and in lysosomes}

Due to their property to cluster at specific vesicles, reggies/ flotillins were considered as the molecules responsible for the lipid raft-dependent, clathrin-, caveolin-, dynaminindependent endocytosis of certain GPI-anchored proteins (Glebov et al. 2006; Ait-Slimane et al. 2009). However, this view was challenged since other investigators could not find a reggie-dependent endocytosis of GPI-anchored proteins nor was the emergence of caveola-like indentations reported to be formed in Hela cells after reggie-1 and -2 overexpression for endocytosis (Frick et al. 2007)observed by other laboratories (Kirkham et al. 2008; Langhorst et al. 2008a; Lundmark et al. 2008; Schneider et al. 2008; and our own unpublished data). Also, the recently published reggie-2 knock-out mouse did not show the expected defect (Ludwig et al. 2010). From our point of view, several observations speak for a reggie-mediated cargo transport (which includes the recycling compartment) towards the plasma membrane. Evidence in support of this view was the implication of reggie in Glut4 translocation to the cell membrane in adipocytes in association with the exocyst (Baumann et al. 2000; Kioka et al. 2002; Chang et al. 2007). In T lymphocytes, reggies form a so-called preformed cap (Rajendran et al. 2003), a circumscribed region of the T cells where the T cell receptor complex (TCR) accumulates upon stimulation. Capping precedes full $\mathrm{T}$ cell stimulation and can be induced by antibody-mediated crosslinking of GPI-anchored proteins such as Thy-1 (Friedrichson and Kurzchalia 1998; Simons and Ehehalt 2002) and the cellular prion protein (PrP). Our results show that Thy-1, as well as PrP, co-cluster with reggie in the cap, an event that activates src and MAP kinases and $\mathrm{Ca}^{2+}$ signaling and which leads to the recruitment of the TCR to the reggie cap (Stuermer et al. 2004). Movies of vesicle trafficking in Hela cells showed that reggie vesicles rapidly shuttle between the plasma membrane and regions further down in the cell, suggesting a function in delivery of components associated with and contained in these vesicles (Langhorst et al. 2008a; Katanaev et al. 2008). Other studies have implicated reggie/flotillin in trafficking of the cholesterol transporter (Ge et al. 2011) in muscle cells and the endocytosis and microdomain localization of DAT (dopamine active transporter) in 
neurons (Cremona et al. 2011), respectively. In macrophages, reggies were, furthermore, found to interact with the motor protein KIF9, which participates in the delivery of vesicles with specific proteases into the podosomes (Cornfine et al. 2011).

Recent evidence suggests a role of reggie in N-cadherin delivery in conjunction with the accumulation of $\operatorname{PrP}$ at cell contacts and in the growth cone periphery in neurons (Bodrikov et al. 2011). Thus, reggies seem to play a role in the transport of specific proteins to very specifc sites of the cell.

The other type of vesicle at which reggies are compellingly abundant are multivesicular bodies (MVB) and lysosomes. Immuno EM analysis has demonstrated that reggies are localized within MVBs and lysosomes (Stuermer et al. 2001, 2004; Langhorst et al. 2008a) and are most likely subjected to degradation-which complies with the fact that the concentration of the reggies within the cell is tightly regulated. Our own unpublished work has demonstrated that expression of dominant-negative forms of specific Rho-GTPases, which co-exist with reggies on specific tubules and vesicles and regulate vesicle sorting and trafficking, causes loss of reggie from these tubules/vesicles and promotes delivery of reggie to lysosomes. It has, moreover, been observed that downregulation of reggie-1 in Hela and N2a cells by siRNAs leads to the degradation of reggie- 2 (Solis et al. 2007) while others have reported vice versa (Ludwig et al. 2010). Together with the fact that reggies form homo- and hetero-oligomers, their joined up- and downregulation suggests that they are perhaps scaffolds of a dynamic tubulo-vesicular compartment whose abundance and efficacy seems to depend on the available concentration of reggie-1 and reggie-2.

\section{Reggies are essential for axon growth and regeneration}

In neurons in culture, both reggies were found to be localized along the entire axon and to be enriched in growth cones and filopodia. This predicts that reggies might regulate aspects of growth cone function and elongation (Munderloh et al. 2009), which was tested by using RNAi- based downregulation, first in embryonic mouse hippocampal neurons and then in the more complex in vivo environment of the adult visual system.

Downregulation of reggie-1 in hippocampal neurons by siRNA transfection severely impaired neuronal differentiation and blocked process formation. The neurons remained alive but appeared abnormally small (Fig. 1). They produced ruffling lamellipodia-like membranous veils but were unable to extend neurites. Occasional neurons with axons carried club-shaped endings instead of growth cones, which failed to elongate (Langhorst et al. 2008b). Most siRNA-transfected neurons neither formed axons nor dendrites. The fact that process extension was partially recovered (in $60 \%$ of the cells) in the parallel rescue experiments (in which reggie siRNAs and reggie-siRNA-resistant-RNA were co-transfected) supports the proposition that the absence of neurites is a reggiespecific loss-of-function phenotype (and not a siRNA-artifact) (Munderloh et al. 2009).

The severeness of this phenotype demonstrates that reggies are necessary for axon growth and for neuronal differentiation. To prove their role in regeneration, a method, pioneered by Becker et al. (2004), was employed that allows the downregulation of the expression of specific proteins in RGCs within the adult animal with the modified siRNAs, commonly known as morpholinos (from work with zebrafish embryos). We applied reggie morpholinos in adult fish to the optic nerve at the time of nerve transection by means of a piece of gelfoam.
Fig. 1 Hippocampal neurons after si RNA mediated downregulation of reggie fails to differentiate and to extend neurites. a Control si RNA; b, c si RNA against reggie; d rescue with reggie RNA; e quantification (from Munderloh et al. 2009). Scale bar $20 \mu \mathrm{m}$
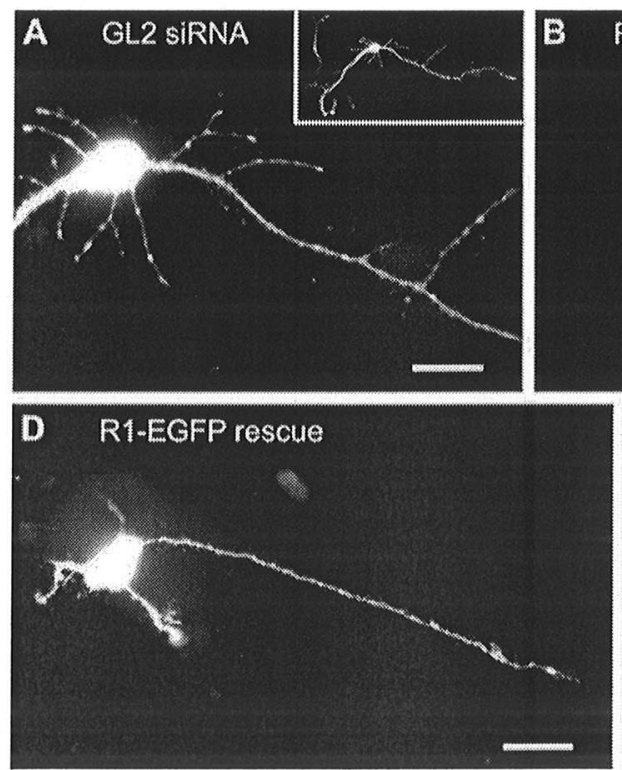
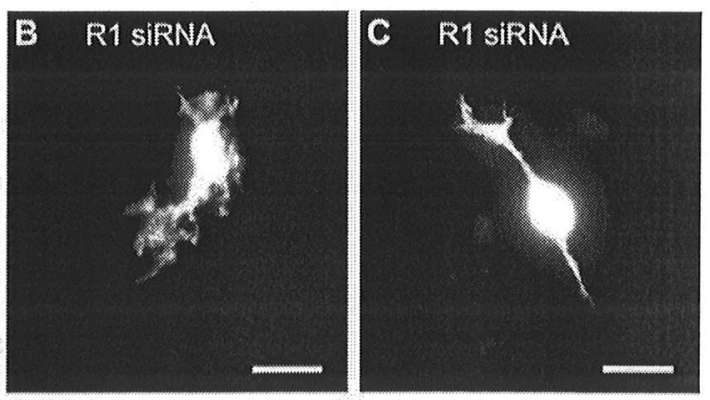

E

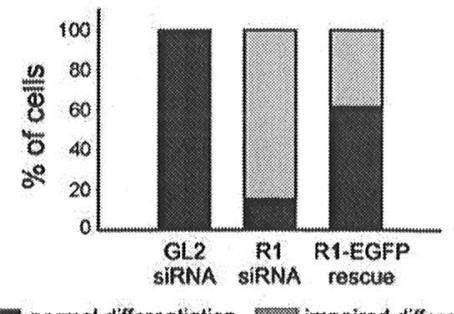

normal differentiation impaired differentiation 
The morpholinos, being fluorescently labeled, are taken up by the severed axons and are retrogradely transported to the RGC of origin where they are identified by their fluorescent tag. Two methods were employed for the evaluation whether reggie downregulation would interfere with axon regeneration in vivo: 4-6 days after morpholino application, the retina was isolated and divided in $200 \times 200 \mu \mathrm{m}$ miniexplants that extend axons (under control conditions). The number of axons from reggie morpholino-treated retinae was reduced to $30-50 \%$ compared to controls. In the second in vivo assay, RGCsafter optic nerve transection and morpholino applicationwere allowed to regenerate their axons for 7 days. Then, a green fluorescent dye (Alexa 488) was applied a few $\mathrm{mm}$ behind the original lesion to the axons that had succeeded to cross the lesion site. The retrograde transport along the axon delivers the dye specifically to the RGCs that had regenerated their axons. Comparison between the control morpholino (right) and reggie morpholino-treated side (left) showed a $70 \%$ reduction in number of Alexa 488-labeled RGCs after reggie downregulation, demonstrating that reggie downregulation robustly reduces the ability of fish RGCs in vivo to regenerate their axons (Munderloh et al. 2009).

The lack of differentiation of reggie siRNA-treated hippocampal neurons and the impaired regeneration of RGC axons in vivo after reggie downregulation are compelling results and suggest that reggies must perform a very basic function in neurons, a function that is needed for the formation of the growth cone and its elongation (Stuermer 2010), axonal transport, vesicle trafficking, cargo supply, or delivery (see below).

\section{Experimentally induced upregulation of reggie in rat RGCs allows axon regeneration in mammals}

The blockage of differentiation in mouse hippocampal neurons had already suggested that reggies do play an important role for axon growth not only in fish but also in mammals. Therefore, we examined reggie expression and regulation in the RGCs of rats. We used rats because a small fraction of RGCs was shown to be able to regenerate axons when the optic nerve with its inhibitory glial cells and CNS myelin is replaced by a PNS graft (Richardson et al. 1980). Reggie-1 and -2 are highly expressed across the RGCs in the rat embryo by in situ hybridization (Lang et al. 1998) but were not detected by this technique in the retina of adults, either normal or after optic nerve lesion. However, specifically, those RGCs that had been able to extend an axon into the graft and that were retrogradely labeled after HRP application, expressed increased levels of reggie mRNAs (Lang et al. 1998). These observations suggest that reggies are needed for axon regeneration in the mammalian CNS.
It has become possible to induce the expression of specific proteins by adeno-associated viral vector (AAV)-mediated transformation of rat RGCs (Planchamp et al. 2008). In a collaboration between M. Bähr's and our laboratory, the AAV transformation of RGCs with reggie-1-EGFP in adult rats was performed in combination with an optic nerve crush (and in parallel to controls receiving AAV-EGFP). The AAV-reggie1-EGFP rats possessed many regenerating RGC axons in the optic nerve that had crossed the lesion and several had extended $5 \mathrm{~mm}$ through the nerve towards the brain - a result rarely seen in controls (unpublished). This nicely confirmed that the forced upregulation of reggie enables neurons even in adult mammals to extend axons through their old pathways and inspite of the glial cell inhibitors. This, together with evidence showing that downregulation of reggie in neurons with spontaneous high reggie expression levels (fish RGCs, mouse embryonic hippocampal neurons) impairs axon extension, highlights the importance of reggie for axon growth and regeneration and also speak for the right choice in naming them "reggie".

\section{How reggies might trigger axon growth}

Several reggie/flotillin interaction molecules were discovered in adipocytes in the context of research aimed at elucidating how glucose transporter (Glut) 4 is delivered to the plasma membrane after insulin stimulation. Reggie/flotillin binds fyn (Liu et al. 2005), as well as the adaptor protein CAP (c-cblassociated protein), which interacts with c-cbl upon activation of the insulin receptor (Baumann et al. 2000). c-cbl acts on the one hand as ubiquitin ligase but activates on the other hand through CrkII, the adaptor protein $\mathrm{C} 3 \mathrm{G}$, the GEF for the small cdc-42-related GTPase TC10 (Kioka et al. 2002). TC10 is not only important in adipocytes, where it participates together with the GTPase RalA in the exocyst-dependent delivery of cargo (Glut4) to the plasma membrane (Feig 2003; Chen et al. 2006; Chang et al. 2007), it and the exocyst are also involved in axon growth (Pommereit and Wouters 2007; Dupraz et al. 2009), which provides a link to a function of reggie in neurons.

As discussed earlier in this article, reggies represent platforms for PrP clustering and signaling in $\mathrm{T}$ cells, which suggested to us that the PrP-reggie interaction might influence aspects of axon growth. Meanwhile, we have demonstrated that $\operatorname{PrP}$ transinteraction $\operatorname{PrP}$ on one cell with $\operatorname{PrP}$ on the opposing cell) is required for the delivery of E-cadherin from internal vesicles to cell contact sites in zebrafish embryos and various mammalian cells (Malaga-Trillo et al. 2009; Chiesa and Harris 2009). In the absence of PrP, E-cadherin remains intracellularly. Ongoing work in epithelial cell lines, designed to test this hypothesis, shows that reggie as well as PrP are involved in cell contact formation and adhesion and both are needed for the proper function of E-cadherin in adherens junctions in Hela and A431 cells (Solis et al. submitted). 
Based on this information, we argued that PrP-reggie interactions might also affect the delivery of important cargo proteins in neurons, i.e., $\mathrm{N}$-cadherin and influence neurite elongation. More precisely, would PrP and reggie-under participation of TC10 and the exocyst-mediate the delivery of $\mathrm{N}$-cadherin to the plasma membrane of axons and growth cones? Since E-cadherin recruitment to contact sites in epithelial cells required PrP-PrP transinteraction, we activated PrP on the surface of neurons by adding the soluble PrP-Fc fusion protein thus mimicking PrP-PrP transinteraction (Bodrikov et al. 2011). This caused clustering of PrP on the axon of hippocampal neurons and, as hypothesized, led to increased coclustering of activated PrP with reggie. This elicited an increased reggie-dependent activation of fyn and MAP kinase and led to a TC10 and exocyst-dependent (100\%) increase of neurite length. Importantly, PrP activation resulted in the recruitment of N-cadherin vesicles to PrP-reggie co-clusters and to the relative enrichment of $\mathrm{PrP}$, reggie and $\mathrm{N}$-cadherin in the growth cones.

The existence of PrP knock-out mice allowed us to show that PrP on the axon is indeed important for these signaling events and for N-cadherin recruitment. Most impressively, while PrP wt neurons more than doubled the length of their axons after stimulation by $\mathrm{PrP}-\mathrm{Fc}$ - in correlation with the increased recruitment of $\mathrm{N}$-cadherin vesicles to the growth in association with reggie, this gain in axon length did not occur in PrP knock-out neurons and was paralleled by the failure of $\mathrm{N}$-cadherin association with reggie (Bodrikov et al. 2011).

These results are relevant in several respects: they show (1) that PrP activation increases growth cone elongation, (2) that PrP activates reggie-associated signaling molecules and (3) that reggie, by co-clustering with PrP, transduces signals that result in the recruitment of $\mathrm{N}$-cadherin to reggie-PrP co-clusters in the growth cone. Here, $\mathrm{N}$-cadherin can trigger axon growth by its associated signaling partners including alpha and beta catenin, p120 and adaptor proteins for the regulation of the actin cytoskeleton. This work shows that reggie-PrP interaction is responsible for the recruitment of specific membrane proteins to specific sites of the cell: N-cadherin into the growth cone, E-cadherin to cell contact sites and the TCR to the T cell cap (Das et al. 2004). This assigns a general cell biological function to reggie and its associates/interacting proteins, which complies with its widespread expression and evolutionary conservation and accounts for the fact that reggies play a role for specific but at the same time very different, membrane proteins in cells as diverse as adipocytes, T cells, macrophages and neurons.

\section{Are reggies involved in the turnover of the growth cone membrane and specific membrane proteins?}

For its elongation with dynamically adjusting spatial cues, the growth cone requires the continuous supply of membrane and membrane proteins, which is, on the one hand, provided by the anterograde axonal transport from the neuron's biosynthetic activity. On the other hand, it has been recognized that, when the growth cone moves forward, not only new membrane plus proteins are added at its egde but membrane plus proteins are simultaneously subjected to endocytosis and recycling (Shao et al. 2002; Falcone et al. 2006). It will therefore be interesting to examine whether reggie and PrP participate in the local recycling and sorting of membrane proteins (such as $\mathrm{N}$-cadherin) in the growth cone (and the axons) (Bodrikov et al. 2011). This view fits several observations including the impaired migration of leucocytes (Rossy et al. 2009), also observed in the reggie-2/flotillin-1 knock-out mouse (Ludwig et al. 2010).

We propose that reggies as intracellular proteins receive signals from the cell surface by communicating with molecules of the extracellular side of the plasma membrane, PrP being one of them. Furthermore, PrP is known to undergo rapid recycling and is, in fact, one of the most rapidly recycled membrane protein (Shyng et al. 1993). PrP clustering, for instance by PrP transinteraction, increases signaling via reggie and spurts the delivery of cargo contained in reggie containers. This implies that the cell surface proteins and their preferential accumulation in the growth cone are causing the preferential delivery of cargo (N-cadherin)vesicles associated with reggie to the growth cone (Fig. 2).

Given that the lesion-induced upregulation of reggie in fish RGCs is a major determinant of successful axon growth and regeneration and that the reggie-dependent cargo

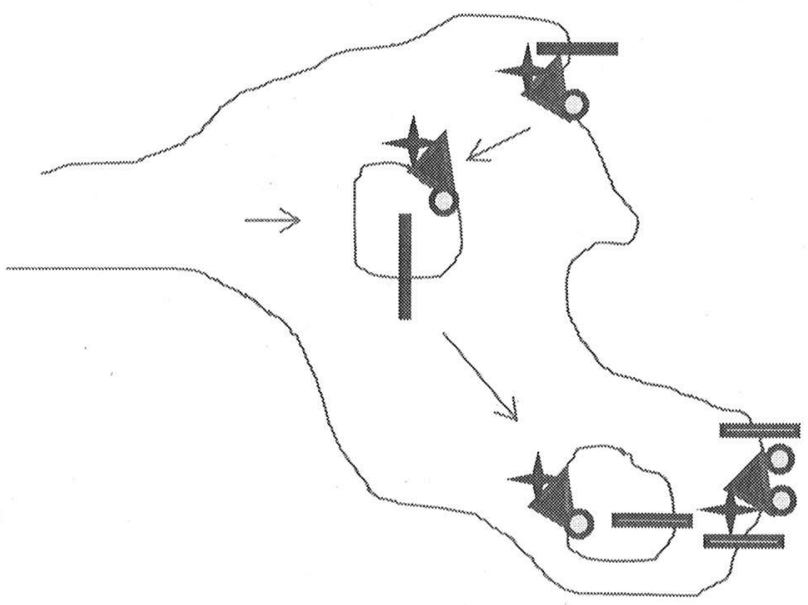

Fig. 2 Reggies regulate the macroendocytic recycling and targeted re delivery $\mathrm{IN}$ cadherin at the elongating growth cone. Growth cone elon gation involves the macroendocytic uptake of membrane proteins such as $\mathrm{N}$ cadherin, local recycling and the re delivery to the growing portion of the growth cone. This process involves reggie at cargo vesicles, mem brane and membrane proteins such as $\mathrm{N}$ cadherin, the interaction of reggie with $\mathrm{PrP}$ and the $\mathrm{PrP}$ and reggie dependent activation of TC10, fyn and Map kinase. (reggie, red triangle, $\mathrm{N}$ cadherin, blue rod, blue star, $\mathrm{TC10}$, fyn and Map kinase, yellow dot, PrP) 
delivery and recycling machinery is a necessary condition/tool for axon growth and regrowth, it will be crucial, on the one hand, to further dissect the exact cell biological mechanisms governed by reggie, such as identification of the mechanism of cargo vesicle selection by reggie and of reggie interacting molecules. Are reggie vesicle-scaffolding proteins and specific for rapid membrane and cargo recycling events? On the other hand, a major challenge for future work is to uncover regulators of reggie expression. It has been suggested that p53 regulates reggie expression in $\mathrm{PC} 12$ cells (Santamaria et al. 2005) but this has not been pursued further. The goal would be to induce re-expression of reggie when needed and to enable a significant proportion of neurons in the mammalian CNS to regenerate axons after lesion.

\section{References}

Ait Slimane T, Galmes R, Trugnan G, Maurice M (2009) Basolateral internalization of GPI anchored proteins occurs via a clathrin independent flotillin dependent pathway in polarized hepatic cells. Mol Biol Cell 20:3792 3800

Baumann CA, Ribon V, Kanzaki M, Thurmond DC, Mora S, Shigematsu S, Bickel PE, Pessin JE, Saltiel AR (2000) CAP defines a second signalling pathway required for insulin stimulated glucose transport. Nature 407:202 207

Becker CG, Lieberoth BC, Morellini F, Feldner J, Becker T, Schachner $M$ (2004) L1.1 is involved in spinal cord regeneration in adult zebrafish. J Neurosci 24:7837 7842

Benowitz LI, Yin Y (2007) Combinatorial treatments for promoting axon regeneration in the CNS: strategies for overcoming inhibi tory signals and activating neurons' intrinsic growth state. Dev Neurobiol 67:1148 1165

Bickel PE, Scherer PE, Schnitzer JE, Oh P, Lisanti MP, Lodish HF (1997) Flotillin and epidermal surface antigen define a new family of caveolae associated integral membrane proteins. J Biol Chem 272:13793 13802

Bodrikov V, Solis GP, Stuermer CAO (2011) Prion protein promotes growth cone development through reggie/flotillin dependent $\mathrm{N}$ Cadherin trafficking. J Neurosci 31:18013 18025

Borner GH, Sherrier DJ, Weimar T, Michaelson LV, Hawkins ND, Macaskill A, Napier JA, Beale MH, Lilley KS, Dupree P (2005) Analysis of detergent resistant membranes in Arabidopsis. Evi dence for plasma membrane lipid rafts. Plant Physiol 137:104 116

Browman DT, Hoegg MB, Robbins SM (2007) The SPFH domain containing proteins: more than lipid raft markers. Trends Cell Biol $17: 394402$

Caroni P, Schwab ME (1988) Antibody against myelin associated inhibitor of neurite growth neutralizes nonpermissive substrate properties of CNS white matter. Neuron 1:85 96

Chang L, Chiang SH, Saltiel AR (2007) TC10alpha is required for insulin stimulated glucose uptake in adipocytes. Endocrinology 148:27 33

Chen MS, Huber AB, van der Haar ME, Frank M, Schnell L, Spillmann AA, Christ F, Schwab ME (2000) Nogo A is a myelin associated neurite outgrowth inhibitor and an antigen for monoclonal antibody IN 1. Nature 403:434 439

Chen XW, Inoue M, Hsu SC, Saltiel AR (2006) RalA exocyst dependent recycling endosome trafficking is required for the completion of cytokinesis. J Biol Chem 281:38609 38616
Chiesa R, Harris DA (2009) Fishing for prion protein function. PLoS Biol 7:e75

Cornfine S, Himmel M, Kopp P, El Azzouzi K, Wiesner C, Krüger M, Rudel T, Linder S (2011) The kinesin KIF9 and reggie/flotillin proteins regulate matrix degradation by macrophage podosomes. Mol Biol Cell 22:202 215

Cremona ML, Matthies HJ, Pau K, Bowton E, Speed N, Lute BJ, Anderson M, Sen N, Robertson SD, Vaughan RA, Rothman JE, Galli A, Javitch JA, Yamamoto A (2011) Flotillin 1 is essential for PKC triggered endocytosis and membrane microdomain 10 calization of DAT. Nat Neurosci 14:469 477

Das V, Nal B, Dujeancourt A, Thoulouze MI, Galli T, Roux P, Dautry Varsat A, Alcover A (2004) Activation induced polarized recycling targets $\mathrm{T}$ cell antigen receptors to the immunological synapse; in volvement of SNARE complexes. Immunity 20:577 588

Dermine JF, Duclos S, Garin J, St Louis F, Rea S, Parton RG, Desjardins $M$ (2001) Flotillin 1 enriched lipid raft domains accumulate on maturing phagosomes. J Biol Chem 276:18507 18512

Dupraz S, Grassi D, Bernis ME, Sosa L, Bisbal M, Gastaldi L, Jausoro I, Cáceres A, Pfenninger KH, Quiroga S (2009) The TC10 Exo70 complex is essential for membrane expansion and axonal specifi cation in developing neurons. J Neurosci 29:13292 13301

Falcone S, Cocucci E, Podini P, Kirchhausen T, Clementi E, Meldolesi $\mathrm{J}$ (2006) Macropinocytosis: regulated coordination of endocytic and exocytic membrane traffic events. J Cell Sci 119:4758 4769

Feig LA (2003) Ral GTPases: approaching their 15 minutes of fame. Trends Cell Biol 13:419 425

Fra AM, Williamson E, Simons K, Parton RG (1994) Detergent insoluble glycolipid microdomains in lymphocytes in the absence of caveolae. J Biol Chem 269:30745 30748

Frick M, Bright NA, Riento K, Bray A, Merrified C, Nichols BJ (2007) Coassembly of flotillins induces formation of membrane micro domains, membrane curvature, and vesicle budding. Curr Biol 17:1151 1156

Friedrichson T, Kurzchalia TV (1998) Microdomains of GPI anchored proteins in living cells revealed by crosslinking. Nature 394:802 805

Gaze RM (1970) The formation of nerve connections. Academic, London

Ge L, Qi W, Wang LJ, Miao HH, Qu YX, Li BL, Song BL (2011) Flotillins play an essential role in Niemann Pick C1 like 1 mediated cholesterol uptake. Proc Natl Acad Sci USA 108:551 556

Glebov OO, Bright NA, Nichols BJ (2006) Flotillin 1 defines a clathrin independent endocytic pathway in mammalian cells. Nat Cell Biol 8:46 54

Hinderhofer M, Walker CA, Friemel A, Stuermer CA, Möller HM, Reuter A (2009) Evolution of prokaryotic SPFH proteins. BMC Evol Biol 9:10

Katanaev VL, Solis GP, Hausmann G, Buestorf S, Katanayeva N, Schrock Y, Stuermer CA, Basler K (2008) Reggie 1/flotillin 2 promotes secretion of the long range signalling forms of wingless and hedgehog in drosophila. EMBO J 27:509 521

Kioka N, Ueda K, Amachi T (2002) Vinexin, CAP/ponsin, ArgBP2: a novel adaptor protein family regulating cytoskeletal organization and signal transduction. Cell Struct Funct 27:1 7

Kirkham M, Nixon SJ, Howes MT, Abi Rached L, Wakeham DE, Hanzal Bayer M, Ferguson C, Hill MM, Fernandez Rojo M, Brown DA, Hancock JF, Brodsky FM, Parton RG (2008) Evolu tionary analysis and molecular dissection of caveola biogenesis. $\mathrm{J}$ Cell Sci 121:2075 2086

Lang DM, Lommel S, Jung M, Ankerhold R, Petrausch B, Laessing U, Wiechers MF, Plattner H, Stuermer CA (1998) Identification of reggie 1 and reggie 2 as plasmamembrane associated proteins which cocluster with activated GPI anchored cell adhesion molecules in non caveolar micropatches in neurons. J Neurobiol 37:502 523

Langhorst MF, Jaeger FA, Mueller S, Sven Hartmann L, Luxenhofer G, Stuermer CA (2008a) Reggies/flotillins regulate cytoskeletal 
remodeling during neuronal differentiation via $\mathrm{CAP} /$ ponsin and Rho GTPases. Eur J Cell Biol 87:921 931

Langhorst MF, Reuter A, Jaeger FA, Wippich FM, Luxenhofer G, Plattner H, Stuermer CA (2008b) Trafficking of the microdomain scaffolding protein reggie 1/flotillin 2. Eur J Cell Biol 87:211 226

Liu J, Deyoung SM, Zhang M, Dold LH, Saltiel AR (2005) The stomatin/prohibitin/flotillin/HflK/C domain of flotillin 1 contains distinct sequences that direct plasma membrane localization and protein interactions in $3 \mathrm{~T} 3 \mathrm{~L} 1$ adipocytes. $\mathrm{J}$ Biol Chem 280:16125 16134

Liu K, Tedeschi A, Park KK, He Z (2011) Neuronal intrinsic mecha nisms of axon regeneration. Annu Rev Neurosci 34:131 152

Ludwig A, Otto GP, Riento K, Hams E, Fallon PG, Nichols BJ (2010) Flotillin microdomains interact with the cortical cytoskeleton to control uropod formation and neutrophil recruitment. J Cell Biol 191:771 781

Lundmark R, Doherty GJ, Howes MT, Cortese K, Vallis Y, Parton RG, McMahon HT (2008)The GTPase activating protein GRAF1 regu lates the CLIC/GEEC endocytic pathway.Curr Biol 18:1802 1808

Malaga Trillo E, Solis GP, Schrock Y, Geiss C, Luncz L, Thomanetz V, Stuermer CA (2009) Regulation of embryonic cell adhesion by the prion protein. PLoS Biol 7:e55

Morrow IC, Parton RG (2005) Flotillins and the PHB domain protein family: rafts, worms and anaesthetics. Traffic 6:725 740

Morrow IC, Rea S, Martin S, Prior IA, Prohaska R, Hancock JF, James DE, Parton RG (2002) Flotillin 1/reggie 2 traffics to surface raft domains via a novel golgi independent pathway. Identification of a novel membrane targeting domain and a role for palmitoylation. J Biol Chem 277:48834 48841

Munderloh C, Solis GP, Bodrikov V, Jaeger FA, Wiechers M, Málaga Trillo E, Stuermer CA (2009) Reggies/flotillins regulate retinal axon regeneration in the zebrafish optic nerve and differentiation of hippocampal and N2a neurons. J Neurosci 29:6607 6615

Neumann Giesen C, Falkenbach B, Beicht P, Claasen S, Luers G, Stuermer CA, Herzog V, Tikkanen R (2004) Membrane and raft association of reggie 1/flotillin 2: role of myristoylation, palmi toylation and oligomerization and induction of filopodia by over expression. Biochem J 378:509 518

Planchamp V, Bermel C, Tönges L, Ostendorf T, Kügler S, Reed JC, Kermer P, Bähr M, Lingor P (2008) BAGl promotes axonal outgrowth and regeneration in vivo via Raf 1 and reduction of rock activity. Brain 131:2606 2619

Pommereit D, Wouters FS (2007) An NGF induced Exo70 TC10 complex locally antagonises Cdc42 mediated activation of $\mathrm{N}$ WASP to modulate neurite outgrowth. J Cell Sci 120:2694 2705

Rajendran L, Masilamani M, Solomon S, Tikkanen R, Stuermer CA, Plattner H, Illges H (2003) Asymmetric localization of flotillins/ reggies in preassembled platforms confers inherent polarity to hematopoietic cells. Proc Natl Acad Sci USA 100:8241 8246

Richardson PM, McGuinness UM, Aguayo AJ (1980) Axons from CNS neurons regenerate into PNS grafts. Nature 284:264 265
Rossy J, Schlicht D, Engelhardt B, Niggli V (2009) Flotillins interact with PSGL 1 in neutrophils and, upon stimulation, rapidly orga nize into membrane domains subsequently accumulating in the uropod. PLoS One 4:e5403

Santamaría A, Castellanos E, Gómez V, Benedit P, Renau Piqueras J, Morote J, Reventós J, Thomson TM, Paciucci R (2005) PTOV1 enables the nuclear translocation and mitogenic activity of flotillin 1, a major protein of lipid rafts. Mol Cell Biol 25:1900 1911

Schneider A, Rajendran L, Honsho M, Gralle M, Donnert G, Wouters F, Hell SW, Simons M (2008) Flotillin dependent clustering of the amyloid precursor protein regulates its endocytosis and amyloi dogenic processing in neurons. J Neurosci 28:2874 2882

Schulte T, Paschke KA, Laessing U, Lottspeich F, Stuermer CA (1997) Reggie 1 and reggie 2, two cell surface proteins expressed by retinal ganglion cells during axon regeneration. Development 124:577 587

Shao Y, Akmentin W, Toledo Aral JJ, Rosenbaum J, Valdez G, Cabot JB, Hilbush BS, Halegoua S (2002) Pincher, a pinocytic chaper one for nerve growth factor/TrkA signaling endosomes. J Cell Biol 157:679 691

Shyng SL, Huber MT, Harris DA (1993) A prion protein cycles between the cell surface and an endocytic compartment in cul tured neuroblastoma cells. J Biol Chem 268:15922 15928

Silver J, Miller JH (2004) Regeneration beyond the glial scar. Nat Rev Neurosci 5:146 156

Simons K, Ehehalt R (2002) Cholesterol, lipid rafts, and disease. J Clin Invest 110:597 603

Solis GP, Hoegg M, Munderloh C, Schrock Y, Malaga Trillo E, Rivera Milla E, Stuermer CA (2007) Reggie/flotillin proteins are organized into stable tetramers in membrane microdomains. Bio chem J 403:313 322

Solis GP, Schrock Y, Hülsbusch N, Wiechers M, Plattner H, Stuermer CAO (submitted) Reggies / Flotillins regulate E cadherin mediated cell contact formation by affecting EGFR trafficking

Stuermer CA (2010) The reggie/flotillin connection to growth. Trends Cell Biol 20:6 13

Stuermer CA, Lang DM, Kirsch F, Wiechers M, Deininger SO, Plattner $H$ (2001) Glycosylphosphatidyl inositol anchored proteins and fyn kinase assemble in noncaveolar plasma membrane microdo mains defined by reggie 1 and 2. Mol Biol Cell 12:3031 3045

Stuermer CA, Langhorst MF, Wiechers MF, Legler DF, Von Hanwehr SH, Guse AH, Plattner H (2004) PrPc capping in T cells promotes its association with the lipid raft proteins reggie 1 and reggie 2 and leads to signal transduction. FASEB J 18:1731 1733

Stuermer CAO, Leppert CA (2000) In: Murray NAIngogliaM (ed) Molecular determinats of retinal axon pathfinding in fish. Axonal Regeneration in the Central Nervous System. Marcel Dekker, New York

Wienke D, Drengk A, Schmauch C, Jenne N, Maniak M (2006) Vacuolin, a flotillin/reggie related protein from dictyostelium oli gomerizes for endosome association. Eur J Cell Biol 85:991 1000 